\title{
The Conquest of Thatôn as Allegory
}

HAVING ESTABLISHED the absence of epigraphy to verify the historicity of Thatôn's conquest by Aniruddha, I now turn to the chronicles, for ultimately the story belongs to them. But since there is no epigraphic evidence for either the event or the place, when, how, and why did the story become part of Burma's chronicle tradition? The questions of when and how are relatively straightforward and answerable, but the question of why is necessarily interpretative and far more problematic.

One of the difficulties in assessing the chronicles of Mainland Southeast Asia lies with our own proclivities to separate, and then see irreconcilable distinctions between history and allegory, empiricism and symbolism, "religious" and "secular," linear and cyclic conceptions of time, ahistoricism and historicism, and diachronic and synchronous approaches to understanding the world. The sources generally fall into two categories: accounts written in Pali and those written in the vernacular, although these are by no means mutually exclusive and easy to separate. In some cases the Pali seems to have incorporated local history from the vernacular, often the only written version of that history we have. But the reverse is also true: myths, legends, and history begun by the Pali chronicles—that is, by the center-have become myths, legends, and history of the folk and periphery.

In other cases "secular" histories have incorporated legitimation criteria and mechanisms from religious histories—such as links to the Buddha or Aśoka-and integrated these with the actual history of kings, known as räjavamsa in the Pali tradition and yazawin in Burmese. And, if one is searching for a linear, historically progressive narrative in the more western and modern (though not postmodern) sense of the term, the largely allegorical, synchronous, and cyclic nature of these chronicles creates not a few problems. ${ }^{1}$

Although it is tempting to regard the process as strictly linear and evolutionary, in fact, most chronicles of Burma and Mainland Southeast Asia have been added to by later authors at one time or another. That means 
information contained in a recently recopied version of an "older" chronicle, say, "A," often has late information taken from chronicle "B" written closer in time to the recopy date. Thus, although "A" may be technically older, the information taken from "B" and placed later in "A," may not be. Simply because the author who wrote "A" lived earlier than the author of "B," it does not mean that "A's" account of a particular event is any earlier than that of "B"; indeed, it may be a much later interpolation. These kinds of nonlinear processes ultimately resulted in the version of the Aniruddha story that has come down to us today.

Yet in order to dispel the Mon Paradigm, it is necessary to use its own, western framework of analysis first, to demonstrate that it has no evidentiary basis. Only after that can the case be made that this approach, in any case, is largely irrelevant to the concerns of the societies that produced the chronicles. Otherwise we would still leave the "history" of the Mon Paradigm intact. I shall therefore begin by making the separations and distinctions decried above, but then attempt to understand the chronicles on their own terms, something the Mon Paradigm never did.

In trying to separate historical "facts" from myths and legends with etiological significance-however modern and discipline-centric the process may be-we find that the "religious" histories written in Pali often took a different path, with a different trajectory and focus all their own, for their concerns were different. They not only deviate from what are the main foci of modern, westernized historians-such as sequence of rule, political boundaries, origins of kingdoms, alliances, and so on-but they also often gloss over what might have been the "secular" concerns of the society in which they were written. In other words, while the more "secular" räjavamsa give priority to dates, kings, battles, and royal genealogy, these kinds of foci are often only incidental to authors writing the history of Buddhism, its relics, or its temples. The perspectives and priorities of the world of Pali literature are, therefore, different from those belonging to the world of vernacular literature, even if they are products of the same society.

We find, for example, that events in Pali chronicles surrounding kings and queens were often garbled and quite "anachronistic," and at other times historically "impossible," especially when time is conflated. But that is because they were never intended to be the framework on which to hang empirical historical "truths." Rather, they were included because they touched upon the sacred: the relics, the prophesied cities, the auspicious events. Yet because these Pali chronicles are sometimes the earliest surviving nonepigraphic sources in Burma, they are still important for finding the kinds of "historical" evidence we seek. And in other ways as well, they often shed light on what had been obscure.

Finally, these Pali chronicles of Mainland Southeast Asia owe many 
of their broader themes and some actual stories to the Dipavamsa, Maha $\bar{a}$ vamsa, and the Cúlavamsa, the earliest extant Pali chronicles that deal with the history of Theravāda Buddhism. But the Southeast Asian chroniclers clearly went well beyond what was taken from the Sinhalese sources, as we saw in the case of King Dhammazedi. In such instances, the "orthodox" Buddhist literature of Śrī Lankka provided only a broad framework while its contents were nearly all Southeast Asian; a process that has been called "localization" in the field.

\section{The Regional Pali, Burmese, and Mon Sources}

With these kinds of issues in mind, let us take a look at some of the Burma and regional chronicles pertinent to the Aniruddha conquest story.

\section{ZATATAWPON YAZAWIN}

A fact quite revealing in itself, the Aniruddha conquest story is not found in what may be the earliest extant chronicle of Burma written in Burmese called the Zatatawpon Yazawin (Chronicle of royal horoscopes). ${ }^{2}$ The earliest portions of this text appear to have been written sometime in the late thirteenth or early fourteenth centuries. Although its original author is unknown, and later hands have clearly added information that takes it into the nineteenth century, internal evidence suggests that the original author was writing towards the end of the Pagán Dynasty and just before the beginning of the First Ava Dynasty in 1364. In part, this is suggested by a phrase which states that "the royal son of Tayôk Pye Min, Thihathuya, rules the current kingdom [or capital]" 3 [my emphasis], which was probably still Pagán or its immediate, brief successor, Pinya. ${ }^{4}$ Both father and son were historical figures, confirmed by epigraphy, who reigned during the last decades of the thirteenth century. The author mentions by name Disāpramok, the famous minister of Tayôk Pye, who journeyed to Peking to convince Kublai Khan not to invade Pagán and left an inscription in 1285 AD describing that journey. ${ }^{5}$ As far as I know, the Zatatawpon is one of only two chronicles ${ }^{6}$ that mention this minister, and thus is another indication that the author may have lived close to the time when the minister was still famous. Thereafter, Disāpramok disappears from historiography until twentieth-century scholars read his inscription and resurrected him as an important figure.

The published text of the Zatatawpon that I use was taken from two extant manuscripts. What the editor considered the better copy was published "as is," while the other was used to help correct discrepancies, clarify, add to, and in other ways, enhance the first. These additions were placed in parentheses. The text has been divided into five sections by the editor. 
The first section of the published text deals with the beginning of the world system, its eras, and the many dispensations of the Buddha. The second starts with the first king of the world, Mahāsamata, and Prince Siddhattha, who becomes the historical Buddha, and continues to Aśoka's reign and the beginning of Burmese history. A history of the Śrī Lankan kings is included in this section, which uses the standard Buddhist texts, such as the Mahāvamsa and the Dipavamsa, along with others such as the Buddhavamsa.

Section three concerns the legendary and historical origins of "Burma," beginning with the Tagaung Dynasty, still considered by the Burmese to be the origins of its culture and people. In fact, the author begins this section by saying, "in this our country of the Myanmā, ..." revealing an early identification of the state with the major cultural group, the Myanmā. ${ }^{7}$ A genealogy of kings is provided, including their kinship ties to their predecessors. In the Burma section, all the kings of the Śrī Kṣetra, Pagán, Pinya, Sagaing, and Ava Dynasties are included, ending with heir apparent Narawara in $1671,{ }^{8}$ an obvious indication that these sections had been added later. The kings' dates of accession, their days of birth in numerals, their years as heir, their regnal years, and their age at and date of death are all given. In terms of regnal years, the Zatatawpon is the most accurate of all Burmese chronicles, particularly with regard to the best-known Pagán and Ava kings, many of whose dates have been corroborated by epigraphy. This again indicates that the original author must have been a contemporary of Thihathu, one of the famous Three Brothers, as he suggested.

After each dynastic list an explanatory section is provided, clarifying or qualifying certain information in the same sort of way we would use footnotes. A few are out of place, which suggests later interpolations. In these "notes" sections, the author would add what he considered additional important information, such as the size of each city, the number of gates it had, and so on. In one case the author states that the "great kingdom of Pugam called Arimaddanā was founded in Sakaraja 23 [661 AD.]" by King Samuddayaza, with the famous nineteen villages as his base of strength; ${ }^{9}$ these villages are very much a part of the legend and history of the origins of Pagán. ${ }^{10}$ Interestingly, the date the author gives for the founding of Pagán is within twenty years of the earliest radiocarbon dates recently procured from the urban settlement area just a few hundred yards outside the gates of Pagán. ${ }^{11}$ The author apparently also had access to earlier records now lost to us, as he calls this section "yazawin mhat chyet akyin" (Summary and notes of chronicles). ${ }^{12}$

Section four has the horoscopes, as diagrams and numerals, of thirtysix select kings of the Pagán, Sagaing, and Ava Dynasties, along with those of some other minor kings, beginning with Sôkkaté (Aniruddha's prede- 
cessor) and ending with the birth year (1607) of Min Yè Yandameik, who belonged to the Second Ava Dynasty. Also commanding horoscopes were the founding of major cities, palaces, exemplary temples, and important events, such as the first time the Mongols sent an embassy to Pagán. Since the horoscopes of later kings, such as Thibaw of the last dynasty, and temples built in the Kônbaung period were included towards the end of the text, it is again obvious that later hands have added to the original.

Section five has various statistical charts and data such as "the great Buddhist cities of Jambudipa," "the 16 great countries," "the 19 great capitals," along with what appears to be actual administrative information, such as those cities in Burma (probably under the First Ava Dynasty) that were required to supply fighting men, the towns and villages belonging to the "Northern Horse" that had to supply various numbers of cavalrymen, lists of governors of certain cities, the royal tax from various regions, and so on.

In the section on the kings of Pagán, Aniruddha is given one short sentence of three phrases, ${ }^{13}$ and the conquest of Thatôn is not mentioned. In fact, Aniruddha is not a hero in this text, the author actually invoking a "massacre of the infants" allegory in the king's unsuccessful search for the prophesied future King Kyanzittha when the latter's birth was announced. Information from manuscript "B" added in parentheses states that the author does not think the story has credibility, and although it is found in the ancient texts, it should nevertheless be considered carefully as it is only what the people have said. ${ }^{14}$ In contrast to the single sentence given Aniruddha, the Zatatawpon gives Kyanzittha two full paragraphs out of a total six for the entire Pagán period. Clearly, the legend of Aniruddha had not yet begun by the late thirteenth century.

\section{ZAMBU KUNGYA}

The next relevant extant text to consider is the Zambu Kungya Po Yaza Mu Haung by Wun Zin Min Yaza, minister to at least two successive kings of the First Ava Dynasty (1364-1527): Mingyi Swasawkè (1368-1401) and Mingaung I (1400-1423). ${ }^{15}$ It may be the oldest text to mention the Aniruddha story, but it tells it in a very different way. In it the rough outlines of the history of Śrī Kṣetra, Pagán, and Pinya are first described. Then the eighteenth-century version of the Zambu, which is more complete, says the following about Shin Arahan and the Aniruddha story.

Nine years after Anawrahta's reign, a high monk came, named the lord arahat, Dwe Arahan, and the king honored him greatly. He was much devoted to the Religion and therefore conveyed the Lord Buddha's tooth relic from China to Ceylon for worship. The Religion flourished greatly. In the year 416 [AD. 1054] 
the King, ministers, officers, people, and monks of Thahton carried the three Pitakas of the scriptures upon thirty-three white elephants to Pagan Arimaddana and brought [took] them there. ${ }^{16}$

Thus, in what is clearly a late copy of the earliest known domestic version of what became the Aniruddha story, the account is actually the reverse of the conventional one, where no conquest is mentioned or implied. Instead, it is the people of Thatôn who go to Pagán with the texts. The story is similar, and relatively close in time, to the narrative provided in the Kalyani Inscriptions, where Aniruddha is said to have taken back with him to Pagán a community of monks to establish the religion there. Although the original palm-leaf manuscript of the Zambu appears not to have survived except as a late 1825 copy, its early parts have been incorporated into a late eighteenth-century text called the Maniyadanabon, from which the above quote is taken. I shall discuss the Maniyadanabon in greater detail below.

\section{YAZAWINKYAW}

About a hundred years later, a chronicle called the Yazawinkyaw appeared. Its earliest parts were apparently written in $1502{ }^{17}$ by the famous monk Shin Thilawuntha. ${ }^{18}$ What is most interesting about his work in terms of the Mon Paradigm is that it did not mention Aniruddha at all, ${ }^{19}$ the bulk of it focusing on the kings of India and Śrì Lanka. This chronicle is, for the most part, a Burmese version of, and taken from, the Mahāvamsa, a text we know was present in Ava at the time. It was mentioned by title in an original inscription that lists the names of 295 manuscripts donated to a library in 1442, at the zenith of the First Ava Dynasty during which Thilawuntha played a very important part. ${ }^{20}$ Only the last sections of the Yazawinkyaw, perhaps less than 10 percent, are concerned with Burma.

In the historical literature of Burma, then, at least in the räjavamsa tradition up to the fall of Ava, the story of the conquest of Thatôn has not yet appeared. Aniruddha is either not mentioned at all (Yazawinkyaw) or given only the briefest of descriptions (Zambu and Zatatawpon). We must suspect, therefore, that the legend of Aniruddha began later and may have become inexorably linked to another legend regarding the conquest of Thatôn found elsewhere. ${ }^{21}$

\section{JINAK $\bar{A} L A M \bar{A} L \bar{I}$}

Aniruddha, said to be one of the greatest kings in early Burma's history, is extolled at length, along with his conquest story, in a chronicle that appeared well after his reign, from a much later, relatively distant, and culturally different polity. The Jinakālamāli, whose title in English is given as 
"The Sheaf of Garlands of the Epochs of the Conqueror," appears about a decade or two after Thilawuntha's Yazawinkyaw. It was originally written in Pali by a Ratanapañna Thera of Chiang Mai, and is dated to $2071 \mathrm{BE}$ (1527 AD) by modern scholars ${ }^{22}$ or to the date at the end of the manuscript itself, $1516 / 1517 . .^{23}$ At best, the text was written almost five hundred years after the alleged conquest of Thatôn and several centuries after Aniruddha's and Kyanzittha's expansion into Lower Burma.

The manuscript from which the published English translation is derived has gone through many revisions. The earliest extant version is the "Ayudhayā" copy, an eighteenth-century palm-leaf manuscript written in a later Cambodian script during the Ayudhayā period prior to 1788. That is, it was written after at least two conquests of Ayudhayā by the Burmese in the mid-sixteenth century and perhaps after the last conquest in the mideighteenth century. The Jinakālamāli went through at least a dozen versions, translated and retranslated from Cambodian to Thai to Pali to French to Thai to Cambodian and back again to Pali. ${ }^{24}$ We also do not know what alphabet was first used to write the original version, Thai or Sinhalese. No original has been found, and only the one palm-leaf copy has survived. The chronicle was also revised at least four times during the Chakri Dynasty alone, whose last "revision," during Mongkut's reign, did not follow the original "Ayudhayā copy" verbatim. ${ }^{25}$ Thus even early Thai nationalism could have been a component in the final Pali version of 1962. ${ }^{26}$ By the time it comes down to us in the English translation of 1968 by N. A. Jayawickrama, the journey the chronicle has taken and the array of sources it has incorporated make it a rather broad compendium of knowledge of several different ages and places, rather than that of a singular time and place. ${ }^{27}$

There are six major sections in the Jinakälamāli, three of which are taken from Sinhalese and other standard Buddhist texts. These deal with the various dispensations of the Buddha, the Recitals, and Buddhism in Śrì Lanka. The fourth section contains the legendary account of the founding of Haripuñjaya and Queen Cāmadevī. The fifth section deals with the kingdom of Chiang Mai; it features Mangrai until his death (Rāma Gāmhèn is just barely mentioned), after which follows a period of unrest. The last section concentrates on King Tilok's accomplishments, even though his greatgrandson, known as "Phra Muang Keo" in the text, is considered the greatest king in Mangrai's line according to the author, who, of course, wrote during that reign. Nonetheless, the religious activities during Tilok's reign seemed to have been more important to the author, for basically the Jina$k \bar{a} l a m \bar{a} l i$ is the account of the arrival of Sìhala orthodoxy-particularly the upasampadā tradition of the Mahāvihāra school-and its spread in Thailand from the end of the fourteenth into the middle of the fifteenth cen- 
tury This is about the same time that Dhammazedi's kingdom was going through the same process with the same school in Lower Burma.

Thus, although relatively distant in time and place from activities in Lower Burma, the Jinakālamāli is important here because it is the first chronicle of Southeast Asia that I know of to actually mention a conquest by an Aniruddha of a kingdom held by one Manohāra. But the story is hardly central to the thrust of the work; instead, it is a digression and only a small part of a much larger and broader Theravāda Buddhist, Mainland Southeast Asian, Chiang Mai legitimation theme. It may, therefore, have been a later addition. Aniruddha's role as a great Buddhist king ${ }^{28}$ is far more important than the conquest story, especially as he plays a major part in the bringing of orthodox Buddhism to Thailand. He is given the credit for bringing to Mainland Southeast Asia what the author considers one of its most holy relics, the Emerald Buddha, ${ }^{29}$ a central motif around which many other important events, including the Aniruddha conquest story, revolve.

The Jewel Image, as the Emerald Buddha is called in the text, was said to have been sculpted miraculously after the parinibbānna of the Buddha in Pātaliputra, Aśoka's capital, an activity in which a host of important deities and super elders were involved. Then came the Kali Yuga, the age of chaos, when the image was taken to the Island of Lanka by "the people" for safekeeping. Finally, around 656 AD, approximately 1,200 years after the Buddha's parinibbānna, the great Buddhist centers of Mainland Southeast Asia enter the picture. At that time Aniruddha of Arimaddana is said to have gone to Śri Lanka with the intention of procuring the Holy Scriptures, and in the process he also obtains the Jewel Image, bringing it to Southeast Asia for the first time. Here, it is clear and significant that Aniruddha attempts to obtain the "holy grail" as it were, not from Lower Burma but from Śrī Lan்ka.

His request for the original scriptures is refused, although the king of Śrì Lañka offers to make a copy for him. Aniruddha, however, tells the king that "your writing . . . does not meet with my approval. I myself will write it down." 30 So he personally copies them, then places part of them on one ship and part on another with the Jewel Image, and returns to Pagán. On the way "a fierce gale" sends one ship to Mahānagara (thirteenth-century Angkor Thom) and the other to Pagán. Soon thereafter, Aniruddha seeks the ship that landed in Angkor. At first, the king of Angkor refuses, but after witnessing Aniruddha's miraculous powers, decides to give the Tipitakas to him. Aniruddha returns to Pagán with the scriptures, but forgets the Jewel Image, leaving it behind in Mahānagara. ${ }^{31}$ In this sequence, the Aniruddha-versus-Manuha trope is recalled once again. 
The narrative then goes through a variety of other personalities and events, both in Śrī Lañka and Mainland Southeast Asia, until one King Ādicca, the lord of the city of Ayojjha, invades Mahānagara and captures the Jewel Image, taking it back with him to his capital and enshrining it there. "The King and the citizens there paid homage to the Jewel Image for a long time," said the Jinakälamā $l i{ }^{32}$ Thereafter, the Jewel Image goes from one city to another via different conquering kings, all within Thailand and possibly Cambodia, providing legitimacy to those cities that manage to house the Image. ${ }^{33}$

Finally, the story leads to an emperor of the "Rammana Country" and a different relic, called the Black-Stone Image. This emperor had taken a sacred black stone and made five Buddha images, depositing one at Mahānagara, one at Lava, one at Sudhamma and, said the Jinakälamāli, "retained two of them here itself in the Rammana Country . . " [my emphasis]. ${ }^{34}$

The last phrase, "here itself in the Rammana Country," is revealing and interesting, for it places the writer (or the original source of this phrase) in the Chiang Mai Valley cultural region, since the text was written there, or at least, from that perspective. However, since the Jinakālamāli also remarked that the inhabitants of the "Rammana Country" speak "their own language," ${ }^{55}$ it sounds as if the language was not that of the author (presumably T'ai) but another, most probably Mon, the most viable candidate for that time and place.

Moreover, throughout the narrative "Rammana" is not spelled "Rāmañña," and such distinctions were surely known to scholars of Pali obsessed with these kinds of details. Although the difference in spelling could simply be the result of the numerous versions the original text has gone through, why did subsequent authors not correct it as they were known to do often? It also does not explain the narrative's sense that these were two distinct places, especially since Sudhamma, normally thought of as the center of the Lower Burma Rāmañña, was already named as a separate place from Rammana in the narrative, one of the five places to receive the Black Stone Image. And if the date given to the original Jinakālamāli is correct (early sixteenth century), by then, both the Mon kingdom of Rāmañña and the city of Sudhamma in Lower Burma were already known as such; they had been around and called that since 1479. So if the Rammana and Sudhamma of the Jinakālamāli were the same as the Lower Burma Rāmañna and Sudhamma, why was that connection (and correction) not made by the author?

Knowing that the Jinakālamāli incorporated much information from the earlier, possibly fifteenth-century Cämadevivamsa (which is the main text we have for Haripuñjaya), and taking the Jinakälamāli narrative as it stands, 
it is tempting to think of the phrase "here itself in the Rammana Country" as a reference to Haripuñaya, a Mon kingdom that indeed preceded Chiang Mai in the same valley and probably laid the foundations for it.

What all this suggests is that Haripuñjaya was once probably also referred to as Rammana ("the Mon Country"). ${ }^{36}$ Later, when the Mon speakers from Haripuñjaya fled the so-called cholera epidemic to Lower Burma, they naturally gave the generic name of their old home to this new place-a common enough practice in world history-which was only subsequently adapted to Pali to become Rāmañña. This situation is about the only one that is able to explain all the variables: two different polities in time and place, whose names though spelt differently meant the same thing, whose people spoke the same language, and whose history seems to be in the correct chronological sequence.

Finally the line of kings in the "Rammana Country" descends to one Manohāra, and with him the story switches to Lower Burma and Rāmañña, where the Jinakālamāli story about Aniruddha's conquest of Thatôn appears.

And it so happened that at that time a king named Anuruddha was reigning in the city of Arimaddana. He possessed supernatural power and had the ability to go through the sky. And he, indeed, sent an envoy to King Manohāra in order to obtain one black-stone image. But on account of his devotion to the Buddha, Manohāra did not give it. King Anuruddha becoming enraged with King Manohāra invaded the Rammana Country with a large armed force, engaged Manohāra in battle, and capturing Manohāra alive returned to the city of Arimaddana. Manohāra too, whilst he was living in the city of Arimaddana had a colossal recumbent image made and honoured it continually. It was there, in that city of Arimaddana that Manohāra passed away. The King, the overlord of Mahānagara, coming to hear of King Anuruddha's devotion to the Buddha, gifted to him the black-stone image which he had been honouring. On hearing this, King Anuruddha had the people bring this black-stone image from Mahānagara and honoured it. ${ }^{37}$

One of the most intriguing features of this narrative is that it mentions for the first time three crucial details: the conquest of Manohāra's city; his capture, exile, and death in Arimaddana (Pagán); and his building of a colossal recumbent image there. Heretofore, no other source, epigraphic or chronicle, domestic or external, contained these three details in the same narrative.

Immediately following the conquest story, the Jinakälamāli switches to the founding of Haripuñjaya by Queen Cāmadevī, who came from Lava bringing with her a black-stone image. This event is said to have taken place 
1,200 years after the Buddha's parinibbānna (about 656 AD). ${ }^{38}$ Although Cāmadevī's place in the narrative does not fit well historically with Aniruddha and his conquest of Lower Burma, it does correspond in time to Śri Kșetra. Therefore, Shorto's suggestion that Sudharma-nagara may be an etymon for some of the titles of Śrī Kṣetra's kings ${ }^{39}$ has some merit, and suggests that the Sudhamma in the Jinakālamāli may not be a reference to Thatôn at all—which, as we have seen, is very late historically-but to Śrī Kșetra and the Pyū instead. On the other hand, the narrative also places Aniruddha's quest for the holy scriptures from Śrī Lañka and Aniruddha's capture of Manohāra all at the same time, as it does Aniruddha's confrontation with a king of thirteenth-century Mahānagara. Everything seems to have been happening at the same time and every major figure and every important place seems to have coexisted.

Thus, making Cāmadevī and Aniruddha contemporaries of each other even though historically separated by about four hundred years, while placing the great Buddhist cities and kingdoms of Southeast Asia and the major events that transpired among them in the same general epoch, must have been deliberate. Even if some of these individuals and many of these kingdoms overlapped historically, the author of the Jinakālamāli appeared to be making the point that they all coexisted within a new "good" age, the one that succeeded the "bad" one, the Kali Yuga, when the Jewel Image was originally taken from Aśoka's India to Śrī Laṅka for safekeeping. And in these kingdoms that belonged to this post-Kali Yuga-Lan̉ka, Lava, Mahānagara, Rammaṇa, Rāmañña, Sudhamma, and Arimaddana-the rulers who preserved and honored the most important holy relics also preserved and perpetuated the religion, the ultimate test of legitimacy for state and leader. To those kings and queens were ascribed the highest accolades, while those who did not, met their just fate.

King Ādicca's conquest of Angkor and the transfer of the Jewel Image to Ayudhayā where it was enshrined as its palladium of state is one such example. Another is Aniruddha's conquest of Thatôn which demonstrated that a weak ruler like Manohāra who does not uphold the religion invariably loses to a strong one who does, while the symbol of power of the vanquished (in this case, the Buddhist scriptures) is also removed and taken by the victor. The Aniruddha story was therefore an illustration of such Buddhist principles. Similarly, that Aniruddha could frighten the king of Mahānagara with his magical powers to give up the rest of the Buddhist scriptures that went astray, was not a statement about their historical contemporaneity, but meant to symbolize the quintessential results of such a meeting between a powerful and a weak Buddhist king. Indeed, that may be the reason Manohāra's formal title in the Kalyani Inscriptions is Sūriyakumāra, the same as that of a historical thirteenth-century Cambodian king ${ }^{40}$ during 
whose reign Angkor's decline accelerated. The name was given to Manohāra for what it represents (like Judas) rather than to identify the actual individual involved.

But there appears to be some historical facts underneath these allegorical statements. The story of Cāmadevī, "daughter of the Universal Monarch," who marries a provincial lord and with her husband subsequently establishes the kingdom of Haripunjaya ${ }^{41}$ is virtually the same one also found in the earliest Mon histories, where Magadu (Wareru) eloped with a daughter of Rāma Gāmhèn ${ }^{42}$ to establish their kingdom of Muttama. Such shared stories among distinct cultures such as (in this case) the T'ai and Mon, suggest that historical links between Sukhodaya and Muttama probably existed. As one historian of Thailand astutely remarked: "The texts of the Sukhothai inscriptions often appear to be a forerunner of the Jinakälamäli." ${ }^{33}$ It also demonstrates that the author was concerned with the relationship between primary sources and history. Nevertheless, what we have in the Jinakālamāli is mainly a standard "plot" with representative characters and events, some clearly historical, but being used whenever and wherever the occasion seems to warrant them. The actual local histories of Burma, Thailand, and Cambodia during this early period had been integrated with universalizing Buddhist themes.

Ultimately, what holds these disparate components together in the Jinakälamāli is the concept of "messianic time," when the past and future come together in the present. And it resembles what we today might call a "synchronous approach" to history and society, exactly what Dhammazedi had done in his Kalyani Inscriptions when he conflated time and place with events and individuals.

Yet it is that very conflation of time, of allegory and history, and of different genealogies and geographies that appears to be bothersome to some of us westernized historians. Our concern with "proper" categories of analysis does not permit us to mix apples and oranges, so that events, stories, and individuals that "belong" to one period of time and place cannot be used in another. For the author of the Jinakälamāli however, that combination was precisely what made his narrative meaningful to both him and his audience. It was a mechanism (his "methodology" in today's jargon) needed to expound what he considered to be universal, religious truths, his ultimate concern.

Remarkably (or perhaps not so remarkably), underneath all this collapsing of time, places, events, stories, genealogies, and individuals, there does lie an actual historical period in Mainland Southeast Asia that would be recognized easily and legitimately identified as a unit by today's historians of Southeast Asia. It also stretched from about the seventh to the early sixteenth centuries, the same period of time in which most of the Jinakäla- 
$m a \bar{l} l$ 's historical and mythical figures, places, and events are paramount. The period includes: the arrival of orthodox Theravāda Buddhism from Śrī Lanka; the zenith and decline of the Pyū in the central Irrawaddy valley and that of the Mon at Dvāravatì in the central plains of Thailand; possibly Cāmadevì's founding of Haripuñjaya; the rise, expansion, and decline of Angkor; the emergence, development, and decline of Pagán and of Ava; the emergence, development, and decline of the most important T'ai polities, such as Lan Na, Sukhodaya, and Ayuthaya; and the establishment and the decay of Rāmañnadesa, the first Mon polity in Lower Burma. This historical period indeed witnessed the birth and decay of the "golden age" of Mainland Southeast Asia and its achievements in religion, literature, and the arts. ${ }^{44}$ To the author of the Jinakālamāli, this exemplary period must have seemed just like the post-Kali Yuga.

It also includes some of the most important historical figures in the region and the events in which they participated or created: the Varmans and Vikramas, founders of Pyu Śrī Kṣetra; Cāmadevī, founder of Haripuñjaya; Vijayabāhu I and Parakramabahu I, great Buddhist kings of Śrī Lan̉ka who reestablished Theravāda Buddhism in their kingdom; Aniruddha, Kyanzittha, and Narapatisithu of Pagán, unifiers and consolidators of that kingdom; Sūryavarman I, and Jayavarman II and VII of Angkor, to whom is attributed much of its greatness; Rāma Gāmhèn and Mangrai of Sukhodaya, responsible for that kingdom's development and expansion; Magadu of Martaban, founder of the first Mon polity in Lower Burma; and Rajadarit, Dhammazedi and Shin Saw Bu of Pegu, who established Rāmañnadesa begun by Magadu.

Thus the symbolic components found in the Jinakälamāli are not without some empirical foundations; messianic time, not without some linear basis; and exemplary individuals, not without some historical reality. Its author simply chose to celebrate the period's kings and queens, kingdoms and cities, and auspicious and powerful events largely with allegory rather than with history. It is not that he was entirely unconcerned with history as we understand it, but that to him, it was only incidental to his priority-religious truth.

However, no cycle is complete until its decay and the rebirth of a new one. In fact, the Jinakālamāli was written after the actual decline not only of the "classical age," when most of these ideal kingdoms and figures had long vanished, but also after some of their successors had emerged and declined. The author was writing at the beginning of the third such cycle of birth and decay, and saw in hindsight the all-important Law of Impermanence at work. Probably one of the more powerful events to have occurred within his own lifetime was the sack of Ava in 1527, the year before he completed the Jinakālamāli. That dramatic event was surely considered auspi- 
ciously didactic enough to reaffirm the author's belief that even a great Buddhist kingdom like Ava was subject to the Law of Impermanence when no great reformer king such as Aniruddha existed to extend it or no holy relic such as the Jewel Image existed to protect it. How much more careful must we of Chiang Mai be, to ensure that such events do not happen here. The Jinakālamāli was, indeed, one of several "Epochs of the Conqueror."

Allegorical or historical, provided the date of 1527 or 1528 for the original text is correct and the account of Aniruddha and Manohāra were part of that original text, the Jinakālamāli is the first record of Aniruddha's alleged conquest of Manohāra that I know of which includes the capture of a king named Manohāra, his building of a colossal recumbent image in Pagán, and his exile and death there. No earlier source that I have found so far has all three components in the same narrative. Indeed, it is the story still told today to tourists by guides in Pagán. ${ }^{45}$

This makes the Jinakālamāli extremely important, for it suggests that this may have been one of the earliest sources from which subsequent versions stem. However, because the Aniruddha and Manohāra story was also meant to be a didactic Buddhist principle, applicable to different times, places, individuals, and events, we cannot subject the story to certain standards of historicity. But that was precisely how the Mon Paradigm approached all chronicles; as if their narratives were meant to represent a strict, western concept of "historical truth" woven around a linear, progressive sequence of actual historical events. The test of their worth was whether the information in the chronicles was empirically verifiable or not. At least two generations of scholarship on early Burma have been based on that principle.

But by doing this, the Mon Paradigm took the Jinakālamāli and other chronicles of Burma out of their broader, Buddhist and Mainland Southeast Asia context, removing the didactic, symbolic, and allegoric intent. It then judged their narratives as if they were meant to be empirical, dealing only with "real" historical events. Rather than viewing the Aniruddha conquest story as a Buddhist allegory of the cyclic, impermanent nature of things-therefore requiring a continuous series of reforms by kings like him-it was analyzed for its empirical, historical value in a western, scientific sense. Under these criteria, of course, the story cannot pass the Mon Paradigm's litmus test and so was dismissed as "false" rather than "true historiography," the actual terms used by Luce. ${ }^{46}$

At the same time, however, to dispel the Mon Paradigm properly, I have had to work within it and use its evidence, categories of analysis, and criteria of historical "truth." Simply declaring the allegorical and symbolic as more important in these chronicles would still leave the Mon Paradigm's "history" intact. What I wanted to do first was to show how its history, using 
its own evidence, categories, and criteria, does not even have an empirical basis, and only then demonstrate that the chronicles can also be read as an allegory of certain Buddhist principles.

\section{NIDĀNA ÁRAMBHAKATHĀ}

Around the same time that the Jinakālamāli was written, the Nidana Árambhakathā, a Mon genealogy of kings, was also said to have been composed, discussed briefly in Chapter Four. Like most Mon texts discussed here, the contents include more than what the title suggests. It has miscellaneous anecdotal material, origins legends, and different traditions and enters into detail only with the reign of King "Manuhaw," when the conquest of Thatôn by Aniruddha is mentioned. However, this account does not have the crucial details found in the Jinakālamāli; it says only that Manuha was taken captive to Pagán. ${ }^{47}$ If 1538 is in fact the original date of those parts of the Nidana containing the Aniruddha story, then this would be the earliest text written in Mon to mention it.

However, there are some problems. First, the Nidāna is only part of a larger work called the "Rāmaññ'-uppatti-dipaka," whose original provenance is unclear, or at least has not been established as earlier than those parts of the Nidāna that contain the Aniruddha story. And as was shown in Chapter Four, some parts of the Nidāna must have been compiled at earliest in the seventeenth century, when de Brito was prominent in Lower Burma, and it may have been him with whom the "Indian" in this story has been confused. ${ }^{48}$ Finally, because most palm-leaf manuscripts do not last more than a 100 to 150 years, the original Nidāna was probably recopied at least two times before it became the basis for the published version, by which time the full-blown narrative of the Aniruddha conquest story first found in U Kala's Mahayazawingyi written around 1720 was already well known.

\section{YAZADARIT AYEDAWPON}

The Yazadarit Ayedawpon, ${ }^{49}$ said to have been written around the same time when the original parts of the Nidāna were composed-that is, during King Bayinnaung's reign (1551-1581) — is the next Mon text relevant to the conquest story. It belongs to a different genre, being technically a pon (story, memoir). Although the term is usually glossed as "biography," pon are not too different in content from yazawin. Apart from the Nidana, whose provenance is ambiguous, the Yazadarit Ayedawpon is likely to be the earliest extant copy of a text regarding the history of the Mon in Lower Burma.

In the published edition I use here, the editor claims that a Mon source with the same title existed earlier, which Bannya Dala, its author, then trans- 
lated into Burmese..$^{50}$ He was a renowned Mon minister who served King Bayinnaung and his predecessor. Most powerful during the period between 1518 and 1572, he was a chief advisor to the king, a writer-scholar, and a general who often took the battlefield personally. He was in charge of building the new Pegu Palace and was an eyewitness to many events, both in the field and at court. He died around 1572, after being assigned to a remote outpost in what is now Thailand, apparently having fallen out of favor with the king. ${ }^{51}$

In contrast to this version is Nai Pan Hla's translation of the same work. The preface to his edition states that there was no Mon palm-leaf manuscript called the Yazadarit Ayedawpon for Bannya Dala to have translated in the first place. ${ }^{52}$ Instead, he writes that there is a two-part Mon text called the Thaton-Hanthawaddy Chronicle. The first part is called Uppanna Suvannbhummi arambhakatha Sudhammavati Siharajadhiraja vamsa kyan, ${ }^{53}$ where the Thatôn Chronicle is found. This, he claims, Bannya Dala skipped and instead started with King Magadu of Hanthawaddy and ended with Yazadarit, which is why he (Nai Pan Hla) gave his work the title Yazadarit Ayedawpon Kyan ${ }^{54}$ Either way, the narrative is still a history of the origins and development of Pegu, not Thatôn, which Nai Pan Hla seems to lament.

At the same time, Nai Pan Hla himself does not provide any further information regarding the Thaton-Hanthawaddy Chronicle, particularly whether its original (none is mentioned) precedes the original Yazadarit Ayedawpon, who wrote it, or its date. ${ }^{55}$ The title of the first part (Uppanna ...), which Nai Pan Hla claims Bannya Dala skipped, sounds very much like an elaborated version of the first of two volumes published at Pak Lat only in 1910 and 1912. Since the presumed antiquity of these manuscripts has not been established, in effect Nai Pan Hla is saying that the sixteenthcentury Mon minister Bannya Dala skipped the Thatôn section of a manuscript that was constructed only in the twentieth century, or at best, whose existence prior to the sixteenth century has yet to be demonstrated.

In contrast, the editors of the recently published Mahayazawinthit (New great chronicle of kings) feel that the Mon Yazawin (Mon chronicle) was actually the text that Bannya Dala translated into Burmese, but that he gave it the title Yazadarit Ayedawpon. In this they more or less agree with Tet Htoot and the editors of the Yazadarit Ayedawpon that I am using here. ${ }^{56}$ The contents of the Yazadarit seem to confirm this view, since the work is less about the king whose name appears on the title than it is a history of the Mon beginning with Wareru; Yazadarit himself does not appear until towards the middle of the text. This, in turn, suggests that the Mon Yazawin is older than the Ayedawpon although the extant copy of the latter precedes that of the former. ${ }^{57}$

In any case, there are, according to Nai Pan Hla, nine versions of the 
Ayedawpon, all in Burmese. Four are said to be palm-leaf manuscripts, one is probably a paper copy, and four are printed or other kinds of compilations. All four palm-leaf manuscripts are copies, the earliest of them is conjecturally dated to 1757.58

Our main concern here is this: the Yazadarit Ayedawpon, one of the earliest extant copies regarding the history of the Mon in Burma, which may have been taken from an earlier Mon source and written by a Mon, does not mention Aniruddha's conquest of Thatôn. Instead, it begins the history of the Mon in Burma with Wareru and Martaban. However, it does have an odd and short, out-of-place paragraph in the middle of Yazadarit's story which states that Aniruddha came searching for the royal relics at Dagôn (not Thatôn), but since there was no prophecy for that event, he could not obtain them and returned to Pagán. ${ }^{59}$ The next paragraph jumps back to Yazadarit and the fourteenth century. Clearly, this is a late insertion taken from the eighteenth-century Slapat Räjawain Datow Smin Ron, to be discussed in greater detail below. Thus the Yazadarit, probably the second oldest extant Burma Mon text, does not mention the conquest of Thatôn.

\section{"GAVAM்PATI"}

The next major Mon-language text to appear is a palm-leaf manuscript called "Gavampati." Although Shorto does not state this in his unpublished translated manuscript, he does write elsewhere that the earliest extant copy of this text may date to $1710,{ }^{60}$ which would make it the third oldest extant copy of a Burma Mon "history" of themselves, assuming the Nidāna's sixteenth-century date is correct. But the date Shorto gives the "Gavampati" seems to be at odds with some of its contents. Internal evidence suggests that at least parts of it may have been inserted later, for it freely uses English terms such as "Tavoy," "Martaban," and "Rangoon" (unless these were Shorto's translations of the indigenous terms) ${ }^{61}$ If the terms are original, they most likely would belong to the period following the First AngloBurmese War of 1824-1826, for even Capt. George Baker's account of Burma in 1759 still used the indigenous "Tavay" for Tavoy, suggesting that the "Gavampati"(or these parts) may have been written after that time. ${ }^{62}$ The "Gavampati" also refers to Tavoy as "the boundary of the Mon country ... [and] because the Buddha sat down there [cross-legged] the place was first called Th(a)way (which means cross-legged), which became corrupted and it is now called Daway or Tavoy." ${ }^{63}$ The word "now" is what reveals in part its lateness, for Tavoy is an English term, while Taway is Old Burmese and goes back to the Pagán period. Even though parts of the "Gavampati" are this late, it still does not contain the Aniruddha story, which means the conquest of Thatôn had not yet emerged as a cause celebre amongst the Mon. 


\section{MAHAYAZAWINGYI}

Then comes a major development: U Kala's Mahayazawingyi, written sometime between 1712 and $1720 .{ }^{64}$ It is the first chronicle of Burma with the most comprehensive and complete version of Aniruddha's conquest of Thatôn. ${ }^{65}$ As noted in Chapter One, he deals with Shin Arahan, King Manuha, the unorthodox Ari monks, the request from King Manuha for the "orthodox" scriptures, the attack on Thatôn, the deportation of the royal family and population of Thatôn, the transporting of thirty sets of the Tipitakas on thirty-two white elephants, and, of course, the story of Manuha in exile and his building of a colossal Buddha image ${ }^{66}$ But it is still unclear how U Kala acquired this fully developed story.

The preface in the published version of U Kala's chronicle, edited by Saya Pwa, generally accepted as the most authoritative, provides a fairly detailed genealogy of the author. He was said to be of the "rich person" (thuthe) class, related to Shan chiefs (sawbwa) on his mother's side and to myosa (literally "town eaters"), or regional administrative officers of the crown, on his father's side. His ancestors were said to have gone back to King Bayinnaung's reign, to the Monyin Sawbwa, whose descendants kept their fiefs and served the crown, including during Bayinnaung's conquest of Ayudhyā in 1563 and his heir apparent's victory over Chiang Mai. Some were appointed myosa over Lower Burma cities such as Wagaru (presumably named after our now famous founder of Martaban). U Kala's mother, Mani Awga, whose father was a court minister, married a rich man of Sinkaing. With this pedigree, it is possible that $\mathrm{U}$ Kala had access to family documents at court that went back to King Bayinnaung's reign (1551-1581) when the Yazadarit Ayedawpon was written. U Kala certainly knew and wrote about Yazadarit, as his chronicle contained the equivalent of over a hundred published pages on Yazadarit's reign alone, ${ }^{67}$ more space than he gives to many other famous Burmese kings. It is obvious he had access to this and other sources from Lower Burma, which was, by then, probably a Mon area.

$\mathrm{U}$ Kala may also have had access to sources such as the Jinakälamāli ${ }^{68}$ perhaps brought back from the conquest of Chiang Mai and pieced together the rest from several similar sources. One of these could have been the Nidāna, if its original main part, the "Rāmaññ'-uppatti-dīpaka," was indeed written in 1538 and, as Shorto claimed, contains the conquest story. But I know of no text in Burma, original or copy, where the Aniruddha conquest account is as complete as U Kala's.

At the same time we must be careful about focusing only on the dates of original compilations. Although an earlier dated source, such as the Jinakălamāli may have contributed some components to U Kala's reconstruction during the Jinakālamāli 's rewriting in the late eighteenth century, it could have easily incorporated what U Kala had written since the first ver- 
sion. This would make it appear that since the finakālamāli is an earlier text, everything in it, including the Aniruddha story, must have been earlier as well, resulting in a false chronology. Unless we are certain not only of the dates when these manuscripts were first written but also what components those originals contained, our analysis is very uncertain because it is based largely on extant copies.

The editor of the Mahayazawingyi also states that U Kala used over seventy texts, including the "Thatôn Chronicle," the "Mon Chronicle," the "Ayudhyā Chronicle," and the "Chiang Mai Chronicle." ${ }^{9}$ Yet none of the earliest extant copies of these chronicles we have today contains the conquest story. Although it is possible that the original "Thatôn Chronicle," presumably written in Mon, may have been older than U Kala's work, the earliest extant copy we have is in Burmese, said to have been copied verbatim from a Mon chronicle only around $1789 ;{ }^{70}$ and it does not mention the conquest story. Neither does the "Mon Chronicle," which, as we have seen, is likely to have been what Bannya Dala translated, later naming it the Yazadarit Ayedawpon. The standard "Ayudhyā Chronicle" 71 also does not mention the conquest story. If the Chiang Mai Chronicle that U Kala was said to have used is a reference to the standard one familiar to Southeast Asian historians; it too does not mention Aniruddha's conquest of Thatôn. ${ }^{72}$ Nor does the Burmese history of Chiang Mai called the Zimme Yazawin, whose earliest extant copy is later than U Kala's work in any case. ${ }^{73}$ And certainly $\mathrm{U}$ Kala could not have gotten his conquest story from the Kalyani Inscriptions since they had nothing to say about it.

The evidence we have suggests that the conquest of Thatôn in its most comprehensive version that has come down to us could not have been written with what U Kala was said to have used. That means he must have had other sources not mentioned by the editor, either now lost to us or about which we know nothing. However, as U Kala's work is by far the most complete of all chronicles written in Burma, there is no reason that the same cannot be true of the conquest story as well. Nonetheless, until there is a better and fuller grasp of the historical as well as literary context in which $\mathrm{U}$ Kala wrote, we may never know why it was with U Kala's chronicle that the story of the conquest of Thatôn finally attains this comprehensive character. What little we know is this.

$\mathrm{U}$ Kala was said to have written his history during the reign of King Taninganwe (1714-1733) of the Second Ava Dynasty, which was known for its resurrection of agrarian Upper Burma as the seat of the entire country after about seventy years of commercial Lower Burma dominance by Pegu. So it is conceivable that the euphoria of returning the capital to the traditional heartland and the desire to reunify the country from there once again was on U Kala's mind when he wrote his history, for during those later 
years of the Second Ava Dynasty, Ava had begun to lose its grip on Lower Burma. Reunification, a process that must begin with reconquering Lower Burma once Upper Burma's human and agrarian resources had been secured, was partially successfully under Kings Anaukpetlun (1605-1628) and Thalun (1629-1648). But this occurred at the beginning of the dynasty when Lower Burma was a depopulated and anarchic region controlled by individual warlords like the Portuguese adventurer de Brito. By the time of King Taninganwe's reign, when U Kala wrote, Lower Burma was no longer under Ava's control; indeed, Ava would soon be taken by Pegu. Perhaps the "conquest of Thatôn" by Aniruddha in the eleventh century as told by the Jinakālamāli and the conquest of all of Western Mainland Southeast Asia by King Bayinnaung in the sixteenth century, revived memories of the glorious past when Upper Burma was perceived to be the "center of the universe." Yet the general tone of U Kala's chronicle is not bombastic, it was rather matter-of-fact and relatively subdued, so it is difficult to attribute such sentiments to him.

It is possible that U Kala's perspective may have been shaped by something else: the religious reforms begun by the earlier kings of the Second Ava Dynasty, known for restoring the Mahāvihāra tradition of Śrī Lañka. The reign of King Thalun particularly was one of the high points of these religious reforms, ${ }^{74}$ as attested by his great work of merit, the Rājamanicūla Pagoda popularly known as the Kaungmhudaw ("royal good deed"), clearly an attempt to duplicate the ancient Sinhalese bulbous-style dagaba of Anurādhapura. ${ }^{75}$ These "new" (really old) religious patterns of the past may have inspired U Kala to write about Aniruddha and Shin Arahan as promulgators of a grand religious reformation, for which, along with various other administrative and political reforms, ${ }^{76}$ the Second Ava Dynasty was also well known.

U Kala's treatment of Shin Arahan in this regard provides some insight. It did not say that the monk was from Thatôn; instead, Arahan was endowed with an immaculate conception. At Indra's instigation, one of the nats in Tāvatimsa was reborn in the womb of a Brahmin's wife, and when the child came of age, he became a monk who grew to be famous in all of Jambudipa, meaning here the civilized Buddhist world or Burma. Saying the religion has not yet been established at Pagán, Shin Arahan went there to do just that. ${ }^{77}$

The story is reminiscent of King Aśoka's conversion by the famous monk Nigrodha found in the Mahāvamsa and the Dipavamsa. ${ }^{78}$ Because religious reforms in the Śrī Lañka tradition inevitably includes the stories found in its chronicle tradition as well, the latter may have been the inspiration for the Aniruddha and Arahan story; perhaps even for U Kala's writing of the Mahayazawingyi in the first place. So far not found earlier in 
Burma, the story of Aniruddha and Shin Arahan was clearly the Burmese equivalent of the Aśoka and Nigrodha tale rediscovered by the religious reforms of the Second Ava Dynasty. Whatever the case may be, U Kala's place in the historiography of Burma certainly needs some fresh and original research.

\section{SLAPAT RĀJAWA}

The next major source relevant to the topic to appear in Burma is the Slapat Rājawaì Datow Smin Ròn (History of kings), written in Mon. The first forty-eight pages of the published and translated work establishes the standard links to the Buddha during the first kalpa (age) when he was King Mahāsamatta. ${ }^{79}$ In a nonlinear manner, "interrupted" by many different subjects, events, and individuals, the narrative moves geographically between Buddha's India and Yangôn until it finally reaches King Aśoka's period of time and his subsequent ascent to devaloka (abode of the gods) whereupon Burma comes into the picture more prominently. Nothing is said of the conquest of Thatôn itself, although similar, perhaps representative events, are mentioned, reminiscent of the Jinakālamāli.

Thus, for example, the Slapat states that "in the time of King Tatabong [Dwattabaung, the founder of the First Srì Kṣetra Dynasty] that monarch came marching down from Tharakhettara [Śrī Kṣetra] with a great army. Having a design to carry away the hair relics, when they began to dig a great storm arose and they were unable to carry out their purpose. He offered a golden umbrella (with) emerald handle and diamond cover, and digging into the southeast set it up there. Then he returned to his own city."

The same story, with a different king, is next described: "In the time of Mancesu [a king meant to be prior to Aniruddha and subsequent to Dwattabaung, although it sounds like Minshinsaw, Alaungsithu's son, who is later than Aniruddha], that monarch came marching down with intent to carry away the relics, and being unable to accomplish his object, he formed a precious emerald into the likeness of an altar, and having buried it on the western side as an offering to the relics of the exalted Buddha, he went up to his own city."

Finally, Aniruddha appears on the scene. "That king came marching down from Pagán with the design of digging up the relics. As soon as the diggers touched earth, and there were twenty men digging the relic chamber, a very severe storm arose, and the whole army of King Anoaratha scattered and fled. King Anoaratha having made gold and silver umbrellas offered them to the relics of the Buddha. Having buried precious gems of other lands to the north-east, he returned to his own place." ${ }^{80}$ The "precious gems of other lands" may have been a reference to the Jewel Image he had obtained from Śrì Lañka, the bone of much contention on Mainland 
Southeast Asia, which suggests that this author may have had the Jinakāla-

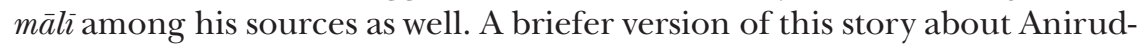
dha in the Slapat had also been stuck awkwardly into the Yazadarit Ayedawpon in the middle of Yazadarit's reign. In any case, the unsuccessful attempts by Upper Burma kings to retrieve the "holy grail," as it were, remain a consistent theme in Mon stories, as does the destruction of the books, according to Shorto, "a favourite myth of the Mon historians." ${ }^{1}$

Note that neither Aniruddha nor the other two kings came down to Thatôn, but to Dagôn (modern Yangôn), where the Shwédagôn Pagoda is located, and all failed to obtain anything: no scriptures, no king, no Mon population, no thirty-two white elephants. There is also nothing about Aniruddha's conversion by Shin Arahan, or Aniruddha's request for the Tipitakas from Manuha-there is, in fact, no Manuha at all-or the refusal of that request, or Aniruddha's consequent attack of the city, or even the establishment of Theravāda Buddhism in Pagán thereafter.

Surely if Thatôn had been perceived to be a great center of Mon Theravāda Buddhism in Lower Burma, which had contributed to the growth of Buddhism in Upper Burma, and surely if such an important event as the conquest of Thatôn had actually occurred, it would have been mentioned by the author of a most important Mon "history of kings." That he does not is particularly puzzling because the author is said to have had many Mon sources in his possession. Yet the first part of this chronicle has nothing whatever of Suvaṇ̣abhūmi or Thatôn, where they "should" have been.

It is true that the Slapat was written by a monk whose main interest was the history of the Shwédagôn Pagoda and the kings (and queen) who patronized it, and so the history of secular rulers per se would have been only incidental to the main thrust of the work. In the introduction and at the end, this religious purpose comes out very clearly. As the author put it, this "history of kings" was meant to demonstrate the Law of Impermanence, that their power and might, their wealth and grandeur, could not achieve "mastery over Death." 82

Thus, Shin Saw Bu, the famous woman sovereign of Pegu, is a major figure and mentioned at length in the Slapat, particularly for her generosity to the Shwédagôn Pagoda. ${ }^{83}$ So is Dhammazedi, who is given a great deal of space in the work for his contributions to the religion and the Shwédagôn, whereas Yazadarit, one of the most famous and powerful kings of Pegu according to both the Burmese chronicles and modern historiography, was not. In fact, in the "Gavampati," he is actually called a demon (raksa). ${ }^{84}$ This neglect of such an important figure as Yazadarit leads me to believe that perhaps the Shwédagôn Pagoda, the centerpiece around which the events and personalities in the Slapat pivot, may not have been built yet even by Yazadarit's reign, for had it been, surely the latter would have donated to it. 
The kinds of political events about which secular authors were concerned were simply not as important to the author of the Slapat, which may account for his omission of Aniruddha's conquest of Thatôn. But that does not explain why the monk included other battles between other kings in Burma, especially during the last decades of the eighteenth century when he dealt with Alaungpaya, De Brito, and others who were clearly not, to him at least, exemplary leaders nor major contributors to the Shwédagôn.

What has become clear is that the idea of a "Mon Lower Burma" may not have been as monolithic as colonial historians have made it out to be, for even at this late date, its literature of legitimation (of which the conquest of Thatôn was crucial), was still being written by different people in different places with different perspectives. That unified narrative would have to wait until 1910 and 1912.

\section{MANIYADANABON}

In the last decades of the eighteenth century, during the reign of King Singu, the immediate predecessor to King Bodawpaya, a monk by the name of Shin Sandalinka wrote the Maniyadanabon. The title can be translated roughly as "the book of precious jeweled precedents," and the bulk of the work is concerned with what the translator calls "submissions," or exemplary advice, from the chief minister to the king. It was probably modeled upon the Indian classic, Milindapañha. Sandalinka's work focused on the First Ava period and Mingaung I, using material from the Zambu Kungya, but he also added submissions from later periods by famous ministers, including Bannya Dala, author of the Yazadarit Ayedawpon. For the translated version of the Maniyadanaboni, Euan Bagshawe used a manuscript that was put into print in 1871 at the court in Mandalay after King Mindon set up a press there. Bagshawe wrote that the Maniyadanabon was one of the first of four Burmese texts selected for machine reproduction, which shows the priority it commanded. ${ }^{85}$

The most detailed and valuable first part of this text, as far as this current study is concerned, consists of information that included the Zambu and Min Yaza's earlier submissions, along with other historical notes that Sandalinka used, especially concerning Mingaung I's reign. After that, the translator writes, the quality declines. ${ }^{86}$ The first part even includes submissions to Yazadarit of Pegu from a monk of Ava. Bagshawe notes that he carried the translation only up to "the death of King Mingaung, where Minyaza himself disappears from the scene." ${ }^{77}$ Thus although the Maniyadanabon was written in 1781, the first section is very likely a good preservation of the late fourteenth-/early fifteenth-century Zambu, parts of which can still be found in the palm-leaf copy of $1825 .{ }^{88}$

At the end of the Maniyadanabon, where Burmese authors of the time 
usually wrote their names and the date of completion, Sandalinka noted that the work was compiled "from the various books of chronicles" in the year 1143 of the Burmese era (1781 AD). ${ }^{89}$ By that time, U Kala's work had been around for over half a century, and Sandalinka, being the recipient of a high royal title under the king's patronage, would have had access to it and other court archives that survived the conquest of Ava in 1752. Nevertheless, Sandalinka's work, instead of creating something new, or continuing the "new" tradition of U Kala's account of the Aniruddha conquest, may have preserved an older, perhaps more accurate version of the story as found in the Zambu, in which a company of monks take the scriptures of Pagán to Thatôn rather than the other way around. This is also what the Kalyani Inscriptions suggest.

\section{MYANMA YAZAWINTHIT}

About the same time that Sandalinka wrote his text, another major Burmese chronicle was written, although the exact date is uncertain. The title of the published version of the first volume is Myanma Yazawinthit (New history of the Myanma [people or country]). It was written by Twinthintaikwun Mahasithu, a highly educated and cultured minister under King Bodawpaya. Twinthin was a well-known monk and teacher before he was made minister, and as a young man in his twenties, he lived through King Alaungpaya's reunification of the country. Knowledgeable in language and literature, poetry, religion, and history, he was a versatile scholar, and along with another minister was subsequently placed in charge of making an inventory of all original religious donations on stone and, in some cases, of recasting them anew. Hence he had access to and was familiar with the information, style of writing, orthography, and so on, contained in them.

In his chronicle Twinthin also accepts the story of Shin Arahan's immaculate conception found earlier in U Kala's work, but Twinthin has Shin Arahan reborn as the son of a Brahmin at Thatôn, who, upon reaching the right age, became a monk. ${ }^{90}$ Since U Kala said nothing about Shin Arahan being born at Thatôn, it appears that Twinthin had added that information, for it is not found in the Maniyadanabon either, whose author was his contemporary.

Why it was important to link Shin Arahan with the city of Thatôn becomes clear only when we consider the story from the perspective of Bodawpaya's reign. The king, like Aniruddha, Dhammazedi, and Thalun before him, considered himself a reformer of the religion and espoused the Sinhalese tradition as orthodox. That means he would have wanted to identify his saingha with Thatôn's, since Dhammazedi had earlier made it the custodian of the orthodox version of the scriptures that stemmed from Aśoka's Third Council originally brought to Burma by Soṇa and Uttara. ${ }^{91}$ 
The link that Twinthin established between Shin Arahan and Thatôn would also provide the correct sort of genealogical relationship between Bodawpaya's saingha and Aniruddha's that Bodawpaya, and virtually all other kings subsequent to Pagán and prior to Mindon's reign, desired. Indeed, Shin Arahan's immaculate conception did not enhance his image as much as his birth at Thatôn did, particularly as one of the members of the orthodox Order.

Twinthin was also familiar with the Kalyani Inscriptions and cites them explicitly with regard to the Aniruddha story. "It is said in the Kalayni Inscription," he wrote, "that when Aniruddha attacked [lup kram] Thatôn, it was weak from hunger...." ${ }_{92}$ But as I have already shown, the Kalyani Inscriptions say no such thing, even if the Pali version does say that the city was "weak from hunger" and that the religion had become impure. Like Luce a couple of hundred years later, Twinthin had associated Aniruddha's reform and Thatôn's decay with a conquest, but he was taking his information from U Kala's chronicle, which he had in front of him. Twinthin had therefore projected Aniruddha's conquest of Thatôn from U Kala onto the Kalyani Inscriptions, not so much, it seems, as deliberate falsification, but probably because by then, like Luce, he already considered it to be common knowledge and historical. But by doing so, he, again like Luce, inadvertently provided false credibility to the story by remarking that it was confirmed in the Kalyani Inscriptions when it was not. ${ }^{93}$

Twinthin's manuscript has another puzzle in it: the number of elephants on which the Tipitakas were said to have been carried to Pagán has grown to thirty-three. ${ }^{94}$ The only other source that has thirty-three instead of the conventional thirty two elephants is the Zambu which had been incorporated into the Maniyadanabon, virtually a contemporary of Twinthin's chronicle. One wonders to what extent Twinthin modeled himself upon famous ministers of old, particularly Min Yaza, who wrote the Zambu. But then the latter work has the Aniruddha story reversed from Twinthin's and U Kala's versions, both of whom had embellished the story even further with their reference to the Kalyani Inscriptions.

There were other "mentalities" working on Twinthin. He seems to have been the first chronicler in Burmese history to name his work after the people or country rather than after various kings. Myanma Yazawin means the "history of the Myanma people [or country]," as opposed to the conventional Maha Yazawin, meaning "history of kings," a distinction that has not been noticed by modern Burma historians for nearly a century now. If the complete title, Myanma Yazawinthit given to the first volume of the published version of Twinthin's chronicle accurately represents the title he gave his manuscript, then it is the first indigenous history written in Burma whose title was focused on the people, country, or state of Myanma, rather 
than on the genealogy of its kings. ${ }^{95}$ It would reveal that Twinthin was thinking in inchoately modern "national" terms, in which "history" was seen as an account of the people, state, polity, or kingdom, and based primarily on the majority group, rather than just its monarchs. It is a conception not found readily (if at all) among his predecessors whose organizational schemes reflected their worlds: a chronology of royalty and their major accomplishments. That same kind of focus on kings and accomplishments also led Thai and Sinhalese Buddhist historians to treat Aniruddha and Bayinnaung as cakkavatti, universal monarchs, rather than as kings who were leaders of national groups. ${ }^{96}$

Similarly, whereas the organization of U Kala's chronicle follows a strict chronology of every king, his offspring and mates, and what they did for the state and religion, without any other divisions into "periods" of history, Twinthin's was one of perhaps only two others to organize history into different periods based on the rise and fall of specific dynasties. ${ }^{97}$ Moreover, the names he gives to these dynasties are not personal ones, such as "the Alaungpaya Dynasty" (an appellation created for the Kônbaung Dynasty by western historians), ${ }^{98}$ but the names of the centers from which they ruled; hence the Pagán Dynasty, the First Ava Dynasty, the Toungoo Dynasty, and so on. The religious reason for this is the thought that these cities had received the all-important Buddha prophecy, usually an honor bestowed $e x$ post facto. ${ }^{99}$ However, organizing history into periods ruled by different centers of power in Burma was quite consistent with his shift in the title of his work from mahayagawin to myanmayazawin.

Thus although Twinthin broke with his predecessors by subtly changing the conceptualization of Yazawin, he nonetheless included the same information contained in the others, revealing that he had similar priorities in terms of content. This comes out clearly in his summary of U Kala's account of the Aniruddha conquest. ${ }^{100}$ A thorough study of Burmese chronicles is much needed.

\section{HMANNAN MAHAYAZAWINDAWGYI}

The next major chronicle to appear is the Hmannan Mahayazawindaw-

gyi. Conventionally translated as the "Glass Palace Chronicle," it should really be called the "Chronicle of the Palace of Mirrors," for it was written in the Palace of Mirrors, one building of the palace complex, by a team of scholars. ${ }^{101}$ Written in 1829 , the compilers used a variety of sources, probably more than U Kala had used, but depended heavily on his work nonetheless. In the Hmannan, Shin Arahan's birth at Thatôn, an assertion begun by Twinthin, has been preserved, after which, the Hmannan quotes U Kala's account of Shin Arahan's immaculate conception and the subse- 
quent attack of Thatôn almost verbatim. ${ }^{102}$ Thus the Hmannan is simply preserving a tradition already well established by previous writers. When its authors disputed earlier accounts, most were of an extremely esoteric nature; there was little substantive critical analysis of sources concerning issues we might consider historically important. As was true with the Slapat, this tells us what the Hmannan's overall purpose was: legitimation according to religious criteria. With regard to the Aniruddha story, it has gone from nothing in the Yazawinkyaw to approximately forty-four printed pages in the Hmannan. ${ }^{103}$ Aniruddha's legend had indeed grown by 1829 .

\section{SĀSANAVAMSA}

In 1861 Paññāsāmi, a monk and tutor of King Mindon, who Mabel Bode called a "high ecclesiastic" and adherent of the traditional Sihala sangha, ${ }^{104}$ wrote the Sāsanavamsa [Chronicle of the religion]. It consisted of ten chapters, each one recounting the history of the religion in different parts of Asia. The third chapter deals with Suvaṇabhūmi, a place by then domestically accepted as the maritime provinces of Lower Burma, even though only a little more than a hundred years ago, U Kala had wondered where it was. The major supernatural figures found in the Yazadarit are mentioned, but a more detailed explanation is given for the genealogy of one of them, Gavampati. ${ }^{105}$

In the Säsanavamsa version, he was said to have been a prince in the city of Mithila in the "Middle Country" (that is, India), a reincarnation of a boy born of an egg (among two eggs), the result of a union between a "knower of charms" and a female serpent. His "brother," from the other egg, became a ruler named Sīharājā in the city of Sudhammapura (Thatôn) that Sakra had built for him. Clearly, there are some differences between the various Lower Burma Mon versions of Gavampati and the Upper Burma version. But the important fact is that the Sāsanavaṃsa, an Upper Burma product, mentioned and incorporated the Lower Burma Mon versions at all, a point to which I shall return. The author then added parenthetically (and erroneously): "in the stone inscription, however, he [Sīharājā] is called by the name of Sirimāsoka." ${ }^{106}$ Even as legend, Sirimāsoka is not Sīharājā; rather, he is the latter's successor, while the "stone inscription" to which Pañnasāmī refers is either one of the three Mon inscriptions of 1486 or the Kalyani Inscriptions, both of which mention Sirimāsoka. ${ }^{107}$

Gavampati, wishing to see and convert his mother, the serpent, now reborn as a human in a country "inhabited by hunters and fishermen," flew to Rāmaññadesa. When he arrived together with his brother, he preached the Doctrine to the inhabitants. It was then that Gavampati decided to ask the Buddha to come to Rāmañna to preach the Gospel, and the Buddha, 
with many "hundred monks came by air to Sudhammapura in the Rāmañna country." 108 Exactly eight years after the parinirvāna of the Buddha, said the author, Gavampati established the religion at Sudhammapura in the Rāmañña country.

According to the Sāsanavamsa, then, it is Gavampati and the Buddha himself who introduce the religion to Suvaṇnabhūmi for the first time, while its second establishment, 235 years later, is attributed to Sona and Uttara. The Aniruddha story follows, but it is exactly the reverse of the conventional one: "the king named Anuruddha of the town of Arimaddana [Pagán] brought an Order of monks from there [Pagán] together with the Pitakas;" 109 so that the third reform of the religion in Suvannabhūmi is attributed to him. However, later in the text the author reverses himself and describes the conquest story in the conventional manner, without providing an explanation. ${ }^{110}$

What can we make of the Sāsanavamsa, which includes two apparently contradictory accounts of the Aniruddha story? First, the text sounds as if it combines different sources without attempting to rectify some of their discrepancies. The story of Aniruddha taking the scriptures to Lower Burma sounds like an extrapolation of the Mahāvamsa story where Vijayabāhu I requests and receives from Aniruddha a chapter of monks and the proper texts in the eleventh century, since Aniruddha would have had to first take them to Lower Burma before they continued to Śri Lanka. The story of the conquest, of course, is the conventional version found in the major chronicles.

Second, one must remember that in the nineteenth century, under the patronage of King Mindon of Mandalay, most Southeast Asian Theravāda Buddhists probably perceived the Burmese kingdom as the premier place where orthodox Theravāda Buddhism had been preserved. There it was patronized by a devout monarch who appears to have been more concerned with his accomplishments regarding Buddhism than anything else, despite British historiography to the contrary. ${ }^{111}$ The Fifth Sāsana Council, held from 1868 to 1871 in Mandalay, the first since the Fourth Council, convened by Parākramabāhu I in 1165, was clearly the most prestigious event in the world of Theravāda Buddhism, and it legitimated king and state in a way that was surely envied by the "international community" of Theravāda Buddhists of the day. No Buddhist king had convened a council for seven hundred years, so that this was indeed an accomplishment of the highest order. The king was following in the footsteps of King Aśoka no less, thereby obtaining the title of "Convener of the Fifth Council" one he treasured beyond all others. ${ }^{112}$ The Tipitakas were "purified" during these three years by a great assembly of learned monks from all over the Theravāda Buddhist 
world and inscribed on 729 marble slabs, each housed in individual shrines, all part of the Kuthodawgyi ("great royal merit") Pagoda that stands today at the foot of Mandalay Hill. ${ }^{113}$ These were, one might say, the "King Mindon Version" of the Scriptures.

In contrast, Śri Lanka by the mid-nineteenth century no longer enjoyed the prestige of being the foremost Theravāda Buddhist country. It was under colonial rule and had been now for several centuries. Lower Burma was also by then under British rule so the religion could not have been considered orthodox there any longer either, especially without a king or a head of the saigha. Upper Burma, however, was still free and had a king and a head of the church, the Thathanabaing, as he was called in the nineteenth century.

Thus the "purity" and orthodoxy of Sinhalese Theravāda Buddhism may have come into question in Burma's highest ecclesiastical circles by that time, while Mandalay in the mid-nineteenth century was probably perceived to contain the most orthodox Theravāda Buddhism in the world. ${ }^{114}$ There was every reason, then, for Paññasāmī, in the religious context of the mid-nineteenth century, to resist the conventional notion that Aniruddha had brought the true religion to Upper Burma from what by then was British-colonized Thatôn.

Third, because Upper Burma by that time had already claimed the orthodoxy of their texts by direct links to the Third Buddhist Council, the historical and secular details concerning such events as Aniruddha's conquest were "mere technicalities" that made little or no difference to devout Buddhists such as the author of the Säsanavamsa, especially when compared with what he considered were the really important events: the religious reforms themselves. Even if such glossing over of historical events makes westernized historians uncomfortable, to Paññasāmì and others like the author of the Slapat, these historical problems were only incidental to the important issue. And that, in the nineteenth century, was that the kingdom of Mandalay, along with its king, its saigha, and its devotees, although hemmed in on all sides by nonbelievers or unorthodoxy, was perceived to be the only center left that defended and preserved the purest form of Theravāda Buddhism.

In sum, the precolonial chronicles contain three basic versions of the Aniruddha story: a) he took the scriptures to Thatôn (the Sāsanavamsa), b) they were brought from Thatôn by the people there (the Zambu), and c) he conquered Thatôn and forcibly took the scriptures back to Pagán (the Jinakālamāli and its successors). Of these, the last has come down to us in Southeast Asian historiography as the orthodox version. And yet it is not the version first found in the indigenous Burmese-Mon tradition but had 
come from outside it-from the Pali Buddhist tradition, where the relationship of Aniruddha and Manuha is more an allegory of Buddhist principles than a historical one, and from the colonial scholarship of the nineteenth and twentieth centuries that had decided to preserve that Pali Buddhist tradition.

\section{PAK LAT MON CHRONICLES}

Finally, in 1910 and 1912 came the first Mon chronicles to contain the conquest story. They were published at Pak Lat, a Mon center in Thailand. ${ }^{115}$ The provenance and chronology of the manuscripts used for these two published volumes are uncertain and still have not been analyzed in any depth by a Burma Mon scholar that I am aware of. They are, therefore, difficult to assess. But what we do know is this.

The first volume, titled Sudhammawati-rājāvaimsa; Siharājādhirājā-vamisa (Sudhammawatī; Gawampatī; Rājādhirāj), ${ }^{116}$ contains three parts, as the title indicates: a short history of Thatôn (the part that Nai Pan Hla claimed Bannya Dala skipped), a section on the "Gawampatī" story, ${ }^{117}$ and a third section called "Yazadarit," a history of Martaban and Pegu from Wareru to Bannya Thau (Shin Saw Bu) of Pegu (essentially, the Yazadarit Ayedawpon.) The second volume, titled Nidāna Rāmādhipati-katha $\bar{a}^{118}$ and published in 1912, apparently contains a brief account of Thatôn, particularly its siege and conquest by Aniruddha, the founding of Pegu, and a brief account of the legendary "first dynasty." This is followed by a brief history of Martaban under Wareru, his successors up to Bannya Thau of Pegu, which again, is probably taken from the Yazadarit Ayedawpon. The second volume is, therefore, more or less the same as the first, with additional parts such as the account of the "first dynasty," added to it. Halliday states that the sketches in the second volume "differ a good deal from those of the other volume though agreeing with them in the main." 119 Nonetheless, as one can see the three segments in each volume present rather clearly Mon myth and history: the first two parts are what westernized historians might call legendary, whereas the third section, beginning with Wareru, is what we might consider "real" history.

There are other difficulties with these two volumes, not the least being their "cut-and-paste" job of reconstruction. In addition, the second volume is said to be particularly difficult to read as it includes many words not contained in James M. Haswell's Mon "dictionary" of 1874 and whose meanings were not known to many literate Mon people in Burma at the time (1913). ${ }^{120}$ That might, at first glance, suggest the text can be dated to earlier than 1874. ${ }^{121}$ But that view was challenged by W. G. Cooper, who argued that most of the unknown words were actually miscopied ones. ${ }^{122}$ It is cer- 
tainly a subject that needs a competent Burma Mon scholar to untangle properly.

It is in the first, 1910 volume that the conquest of Thatôn by Aniruddha and the Mon Paradigm finally makes the "front page" in a Mon text. It reads:

Now the king of Arimaddanapura [Pagán] mustered his army and rode his horse . . . and came to the city of Thaton in the land of Thudammawadi. He compassed it round about and beleaguered it for three months straitly. And those within could get neither food nor drink, and they were exceedingly famished, and so great was their hunger that they ate one another; and many perished thereby. ... Then the folk could no longer abide such sufferings; and on the morning of Monday the eleventh waxing of Nayon, the moon being in the mansion of Visakha, in the year 42, king Manuha rendered himself. And the king of Arimaddanapura, having possession of king Manuha, took away the saintly monks, who were full of learning and piety; he took away the monks who knew the Three Scriptures and the Four Books of Divination, ... he took them all to the land of Arimaddana. He chained king Manuha with golden chains and led him captive. From that time henceforth Thaton was desolate, but Pagan that is called Arimaddana flourished like unto a heavenly city. ${ }^{123}$

Whereas neither the Yazadarit Ayedawpon of the sixteenth century, ${ }^{124}$ the "Gavampati" and Slapat of the eighteenth, nor the early nineteenthcentury Lik Smin Asah ${ }^{125}$ once mentioned Aniruddha's conquest of Thatôn, this first volume published in $1910 \mathrm{did}$, and then in a very emotive style. What this means is that the first time Aniruddha's conquest of Thatôn appears in its full-blown version in a Mon text is the twentieth century! This is a very late realization of the story, myth or not, but one consistent with their late view of Thatôn as an exemplary center.

\section{Conclusion}

The story of the conquest of Thatôn by King Aniruddha in 1057 apparently does not go back to any single source, although it appears that the Jinakāla-

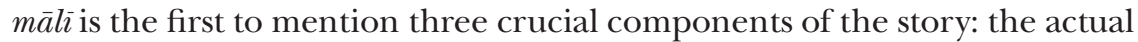
conquest of Manohāra (no city was mentioned), his exile in Pagán where he died, and his building of a colossal recumbent image of the Buddha in Pagán. Although the Nidāna Árambhakathā, written about the same time, is said to have made a brief statement about the conquest, that section cannot be securely dated and it does not have the details that the Jinakālamāi 
has. Subsequently, the story was embellished, added to, and enhanced by U Kala's full-blown version, the one most familiar to scholars today.

It did not seem to matter to modern historians that some of the later texts that mentioned the Anriuddha conquest were found in late palm-leaf copies that had gone through numerous versions, most of unknown provenance, and all with obvious late additions. Neither did the fact that many of these texts had integrated allegory with history, which colonial and postcolonial scholars advocating the Mon Paradigm made little or no genuine attempt to understand in any case. The only textual exegesis they conducted was to search for "empirical truth," so that the narratives in these texts were taken at face value and placed in a historical "true or false" framework of analysis while the rest was more or less discarded. The approach was essentially self-serving, allowing one to verify what one wanted to verify, and reject what one wanted to reject. Thus it was with the story of Aniruddha's conquest: colonial historians never once considered it to have been anything but historical, while virtually everything else that stood in its way was rejected as "false historiography." 126

What they missed, and to me one of the most interesting aspects about the story of Aniruddha's conquest of Thatôn and Manuha, is the fact that it is not found in the earliest of either the Burman or Mon traditions where one would have thought it began, but in a broader Pali Theravāda Buddhist tradition of at least four Theravāda Buddhist countries-Burma, Śrī Lañka, Cambodia, and Thailand-who all shared a chronicle tradition based on Śrì Lañka's Mahāvamsa. Thus its meaning clearly lies in that tradition.

Yet it was removed from that broader culture and placed in what was thought to be a distinctly Burma tradition. This was done by later indigenous chroniclers and modern historians, probably one of the more important mistakes they made, for the text cannot be taken out of its Buddhist context. The "Aniruddha tradition" was not meant to be an exclusively Burma story; it belonged to all the Theravāda Buddhist countries of Mainland Southeast Asia that traced their orthodoxy to the Śri Lankan chronicle tradition, ${ }^{127}$ much like the story of King Arthur that belonged not only to the Britons but also to their rivals, the Anglo-Saxons and Picts, and later to the French and Germans as well.

As in Europe, at the time these Pali chronicles were written about Aniruddha, there were no nations in the modern sense, with irrevocable boundaries within which lived citizens clearly conscious of their identity as Burmans, Thais, or Cambodians. Aniruddha, as a great Theravāda Buddhist king, belonged to everyone in that tradition. That is one of the main reasons the earlier Northern Thai and the later mainstream Thai chronicles recount Aniruddha (and also Bayinnaung) as ideal Buddhist kings, cakka- 
vattis, ${ }^{128}$ not Burman kings who reigned in a country called Burma with a distinct Burman identity. Aniruddha ruled from a great Buddhist city called Arimaddanapūra, which was not, at the time, the capital of a Burman nation, although inhabited mainly by Burmese speakers, but an exemplary Buddhist center, a microcosm of Tāvatimsa, the most cherished of Theravāda Buddhist heavens.

In the same way, the Kalyani Inscriptions depicted Aniruddha, Aśoka, and Parākramabāhu I-and of course King Dhammazedi who erected the stones-as quintessential models of righteous Buddhist kings, and not national monarchs. These kings were intimately involved in keeping the religion pure (because it inevitably decays according to the Law of Impermanence) until Maitreya returns in 5,000 years to preach the dhammacarka, the ultimate sermon, that will save all who are fortunate enough to be reborn as humans in his dispensation.

Dhammavijaya, "righteous victory," in the name of the religion, in which the reformer king searches for and obtains the most orthodox versions of the Holy Scriptures and relics, is very much a crucial part of that reformist theme. That was the reason Aniruddha's trip to Śī Lanka is necessary, where he successfully obtains the Tipitakas and the Jewel Image. That is probably also the reason the Jinakālamāli states that he obtained the scriptures originally from Śrī Lanka (at the time considered the most orthodox land) rather than from Thatôn (which was probably just recently founded and therefore deserved no such recognition), particularly since Śrì Lañka itself had obtained the orthodoxy of its scriptures from Aśoka's Third Buddhist Council.

It is for these reasons that Dhammazedi mentioned Aniruddha at all in his inscriptions, for he was a reformer king whose example Dhammazedi was following. There is no mention in his Kalyani Inscriptions of a conquest of Thatôn, as Twinthin and later scholars alleged, ${ }^{129}$ not only because it did not occur, but because there was no reason to mention it. For Dhammazedi, Thatôn was part of the Manuha, not the Aniruddha story, to illustrate what happened when Buddhist kings allowed the religion to decay. Only in that context is Manuha part of the overall theme: he is a model that represents the antagonist par excellence succumbing to the protagonist Aniruddhas of Buddhist history.

There is another component here that should not be missed. Because the Jinakālamāli has Aniruddha obtaining his pure scriptures from Śrī Lanka and not from Thatôn, it suggests that its author, Ratanapañna, a monk writing in Chiang Mai, did not recognize Dhammazedi's claims in his various inscriptions that Sona and Uttara came directly from Aśoka's Third Buddhist Council with the orthodox texts to Thatôn. Or perhaps Ratana- 
pañna did not know about those claims at all, although they were made over half a century before he wrote the Jinakālamāli.

Yet by the time both the Jinakālamāli and Dhammazedi's Kalyani Inscriptions were written, although both showed concerns of a broader Theravāda Buddhist Śrī Lañkan orthodoxy, they also revealed some parochialism. For even though Dhammazedi was saying, in effect, but quite explicitly as well, that he was, like the great reformer kings of the past, he also needed to link his local legitimacy with Aśoka's Third Council somehow. So he used the story in the Dipavamsa of the mission of Sona and Uttara, deftly switching the location in his Kalyani and Shwédagôn Pagoda Inscriptions and placing it in Lower Burma.

Thus at the very least, the historiography concerning the arrival of Theravāda Buddhism in the region should be emancipated from the bondage of its own mythology, so that one now has the option of not viewing the story of Sona and Uttara's journey to Southeast Asia in the Śri Lankan sources as historical. This was difficult to do heretofore, as their alleged conversion of a Mon kingdom in Lower Burma to Theravāda Buddhism somehow had to be accommodated.

In the case of the Jinakālamāli, of course, the localizing focus was Chiang Mai, even if its history was placed in a broader Theravāda Buddhist orthodoxy. One can now also take a fresh look, in either an empirical or allegorical sense, at other narratives in the Pali chronicles concerned with the great Buddhist heroes and heroines of Southeast Asia, such as Aniruddha and Cāmadevi, and kingdoms, such as Sudhamma and Haripuñjaya, without being concerned that the presence of Rāmañnadesa in Lower Burma might contradict it.

Indeed, the entire relationship amongst the Burmese, Sinhalese, and Northern Thai chronicles, especially those originally written in Pali needs reassessment outside the Mon Paradigm. How are the Mahāvamsa's stories about Aniruddha, Vijayabāhu, and the relics; the Jinakālamāli's account of a conquest of a Sudhamma and its king Manohāra; and the Burmese narrative of Aniruddha's purification of Pagán with monks from Thatôn, textually related? And why was U Kala's description of the Thatôn conquest the first and most comprehensive one? Was there an Ur text that I have missed, or did he put together the story for the first time from a variety of texts which in the context of the reformist policies of his period favored such an interpretation? Certainly the Mon chronicles are part of this issue and need to be studied in much greater detail, but they must be analyzed outside the framework of the Mon Paradigm as well. Of particular concern are the Pak Lat Chronicles. They were used as if they were much earlier, but they are actually part of early twentieth-century Mon nationalism and need 
to be assessed in that modern context by scholars competent in the Mon language.

Beginning with U Kala, the story of Aniruddha's conquest of Thatôn was removed from the larger Theravāda Buddhist orthodoxy and its broader application region-wide to become, instead, an integral and exclusive part of Burma's national history. That may explain why there is no contemporary evidence for it: it was part of a later legitimation and localization (or parochialization) process that continues today. 